\title{
The Significance of Contractual Intention: A Comparative Analysis on English and Indonesian Law
}

\author{
Ulya Yasmine Prisandani \\ Law Study Programme of President University \\ Jababeka Education Park, Jl. Ki Hajar Dewantara, Cikarang Utara, Bekasi 17550 \\ yasmineprisandani@gmail.com
}

Received: 31 Agustus 2018; Accepted: 8 Oktober 2018; Published: 17 Januari 2019

DOI: 10.20885/iustum.vol25.iss3.art4

\begin{abstract}
The legal terms of a contract vary from one country to another, and the will in a contract often influences whether a contract has been perfectly established. Establishing a contract between parties from different legal systems has the risk of defect and imperfection in the establishment of the contract, which can influence the rights of one party when a contract related dispute occurs. The British law requires supply, acceptance, and reciprocity as legal conditions for contracts, but the legal terms of a contract in Indonesian law are stipulated in the Civil Code. Therefore, this study aims to develop a comparative analysis relating to the role of contractual will in determining the validity of a contract in British and Indonesian laws as well as their method in interpreting contracts. The study used the normative qualitative method with a comparative approach to the two legal systems completed with a description of the will in a contract based on CISG. Both legal jurisdictions are open for the possibility of assuming will incompatibility in a contract as 'oversight', and in such cases, a contract can deem void.
\end{abstract}

Keywords: Will in a contract; contract validity; contract interpretation; law of contract

\section{Abstrak}

Syarat sah kontrak berbeda dari satu negara ke negara lainnya, dan kehendak dalam suatu kontrak seringkali mempengaruhi apakah suatu kontrak telah terbentuk dengan sempurna. Pembuatan suatu kontrak oleh pihak yang berasal dari sistem hukum yang berbeda mempunyai resiko kecacatan dan ketidaksempurnaan dalam pembentukan kontrak tersebut, yang mana ini dapat mempengaruhi hak salah satu pihak jika terjadi perselisihan terkait kontrak. Hukum Inggris mensyaratkan penawaran, penerimaan dan timbal balik sebagai syarat sah kontrak, tetapi syarat-syarat sah kontrak dalam Hukum Indonesia diatur dalam Kitab Undang-Undang Hukum Perdata. Oleh karena itu, tulisan ini bertujuan membuat sebuah analisis komparatif terkait dengan peran kehendak kontraktual dalam menentukan keabsahan sebuah kontrak di dalam hukum Inggris dan Indonesia, serta metode penafsiran kontrak di dalamnya. Penelitian dilakukan menggunakan metode kualitatif normatif, dengan pendekatan komparatif terhadap dua sistem hukum tersebut yang ditambah dengan uraian mengenai kehendak dalam kontrak berdasarkan CISG. Kedua jurisdiksi hukum membuka kemungkinan untuk menganggap ketidakcocokan kehendak dalam suatu kontrak sebagai 'kekhilafan', dan dalam kasus seperti ini sebuah kotnrak menjadi dapat dibatalkan

Kata-kata Kunci: Kehendak dalam kontrak; keabsahan kontrak; penafsiran kontrak; hukum kontrak 


\section{Introduction}

The existence of commercial contracts which involve parties originating from different legal systems become inevitable as the number of cross-border transactions between private parties significantly increase. Aided by globalization and advanced technology in the current era, contract has evolved into a matter that is more intricate and exhaustive with each and every articles negotiated carefully by the parties to prevent substantial complication shall a dispute arise in the future. However, different legal systems applied in different legal jurisdictions can exert influence in how the parties interpret the validity of their contracts in the case of a dispute.

The requirements for validity of a contract vary from one jurisdiction to another especially when it comes to the different systems in the civil law and common law countries even though over the years, the civil law and common law systems have found their intersections though in a limited extent. ${ }^{1}$ Though often having minor differences within their national legal systems, ${ }^{2}$ common law jurisdictions recognize offer, acceptance, considerations, intent, and bargaining actions as factors of validity of contract, ${ }^{3}$ whereas in the civil law jurisdictions the requirements are vastly dissimilar. An example would be the absence of the concept of consideration in civil law countries, which constitute a large number of countries in the world. 4

Failure to recognize these differences, as well as taking these factors into account prior to the conclusion of the contract will cause risk of unenforceability due to the disputed binding nature of the contract. This is especially true because even though Indonesian law is originated from Dutch contract law during the colonial period, many principles and concepts from common law legal system are

${ }^{1}$ Charles Calleros, Cause, Consideration, Promissory Estoppel, and Promises Under Deed: What our Students Should Know about Enforcement of Promises in A Historical and International Context, Chicago-Kent Journal of International and Comparative Law Volume 13, (2012), p. 88.

${ }^{2}$ For example see Syed Robayet Ferdous, Consideration of Contract in English Law \& Law of Bangladesh: A Comparative Study, Asian Affairs Volume 31 Number 1, 2009 for the differences of the doctrine of consideration between English law and Bangladeshi Law; see also M.P. Chandrika, A Comparative Analysis of U.K. and Indian Provision relating to Intention under Law of Contract, International Journal of Law and Legal Jurisprudence Studies Volume 3 Issue 4, 2016 for the differences in the concept of contractual intention under English and Indian law.

${ }^{3}$ Kevin J. Fandl, Cross-Border Commercial Contracts and Consideration, Berkeley Journal of International Law Volume 34 Issue 2, Fall 2016, p. 3.

4 ibid., p. 5. 
adopted by various contracts through specific clauses, such as arbitration or choice of law clause. For this reason, it is important for parties to understand each elements required to create a valid contract, one of which being the parties' contractual intentions.

'Intention' can be defined as "the state of mind of one who aims to bring about a particular consequence ${ }^{\prime \prime}$ whereby contractual intention herein means the state of mind of the parties aiming to enter into relation and be bound by a contract. In various jurisdictions, contractual intention plays a vital role in determining whether the parties are bound by an agreement ${ }^{6}$ and as such, impacts the stance of validity of contract. Also known as 'intention to create legal relations', contractual intention is more often discussed and examined within the common law legal systems. Such 'intention to create legal relations' is required in several common law jurisdictions such as under the English and American legal systems, but other common law jurisdictions such as inter alia, India, does not impose such requirement.7 Taking the specific example of English law, intention becomes part of the requirements of validity of contract by virtue of the doctrine of consideration or the use of a deed. ${ }^{8}$

In contrast, the role of contractual intention under Indonesian law also has vital importance since it is related to the first requirement of validity of contract under Article 1320 of the Indonesian Civil Code, ${ }^{9}$ where the parties must express their consent to be bound by the agreement (de toestemming van degenen die zich verbinden). ${ }^{10}$ In general, disputes regarding contract law usually revolve around the issue of validity of contract, and more often the emphasis is directed towards consent of the parties. The principle of consent is very important in contract law, especially with regard to the formation of contract as it is considered to be an absolute requirement in every contract that provides legal certainty for the parties

${ }^{5}$ Elizabeth A. Martin, Oxford Dictionary of Law, Fifth Edition, Oxford, 2003, p. 257.

'Bhawna Gulati, "'Intention to Create Legal Relations': A Contractual Necessity or an Illusory Concept", Beijing Law Review Volume 2 Number 3, 2011, p. 127.

${ }^{7}$ Ibid.

8John Cartwright, Contract Law: An Introduction to the English Law of Contract for the Civil Lanyer, Third Edition, Oxford, 2016, p. 155.

${ }^{9}$ Fani Martiawan Kumara Putra, "Paksaan Ekonomi dan Penyalahgunaan Keadaan Sebagai Bentuk Cacat Kehendak dalam Perkembangan Hukum Kontrak", Yuridika Volume 30 Number 2, May 2015, p. 233.

${ }^{10}$ Muhammad Syaifuddin, Hukum Kontrak: Memahami Kontrak dalam Perspektif Filsafat, Teori, Dogmatik, dan Praktik Hukum (Seri Pengayaan Hukum Perikatan), CV. Mandar Maju, Bandung, 2012, p. 110. 
involved. ${ }^{11}$ The principle of consent has been elaborated pretty thoroughly in many countries, including in the New Civil Code of The Neherlands, as well as in various universal model laws on contract such as the Principles of International Commercial Contracts ${ }^{12}$ and the Principles of European Contract Law ${ }^{13}$, also in international conventions such as the United Nations Convention on Contracts for the International Sale of Goods (CISG) ${ }^{14}$. Additionally, the Draft Common Frame of Reference even goes further by stating that consensus (agreement) followed by the intention to conclude a contract would suffice in establishing a contract, without needing any other elements. ${ }^{15}$

Consequently, further assessment on how contractual intention actually impacts the validity of contract especially in relation to the requirement of consent may be beneficial, since the Indonesian Civil Code has yet to set out an express provision with regard to the matter in question.

A real manifestation of intention includes consent of the parties upon signing the contract. Lack of intention or mistake in the intention, ergo false consent, may cause a contract to be nullified under common law by virtue of the doctrine of mistake ${ }^{16}$, whereas in comparison, Indonesian law regards this as a subjective requirement of validity of contract under Article 1320 of the Indonesian Civil Code, and hence, does not automatically nullify a contract.

\section{Research Questions}

This paper seeks to provide answers and comparative analysis with regard to the significance of contractual intention within the sphere of English and Indonesian contract law, and as such, is based on the following research questions; how do English and Indonesian law assess contractual intention of the parties and

\footnotetext{
${ }^{11}$ Y. Sogar Simamora, Hukum Kontrak: Prinsip-Prinsip Hukum Kontrak Pengadaan Barang dan Jasa Pemerintah di Indonesia, LaksBang Pressindo, Surabaya, 2017, p. 173.

${ }^{12}$ See Article 2.1 - 2.13 of the Principles of International Commercial Contracts on Formation.

${ }^{13}$ See Article 2.101- 2.211 of the Principles of European Contract Law.

${ }^{14}$ See Article 14-24 of the United Nations Convention on Contracts for the International Sale of Goods.

${ }^{15}$ Agne Tikniute and Asta Dambrauskite, "Understanding Contract Under the Law of Lithuania and Other European Countries", Jurisprudence Volume 18 Issue 4, 2011, p. 1402.

${ }^{16}$ For further information, see for example E. Sabbath, "Effects of Mistake in Contracts: A Study in Comparative Law", International \& Comparative Law Quarterly, Volume 13 Issue 3, 1964.
} 
to what extent does contractual intention affect validity of contract under English and Indonesian law?

\section{Research Objectives}

This paper aims to analyze the concept of contractual intentions within the framework of both English and Indonesian legal systems, as well as to analyze further the stance of such concept in relation to providing a better understanding and more thorough knowledge about how contractual intentions can be regarded differently in the two legal systems. Further, analysis is also conducted on how the two legal systems assess contractual intention of the parties - as it is not always manifested or visible, and also whether it affects the validity of contract under each corresponding legal systems.

\section{Research Method}

Research is a process that seeks to define, describe and explain a topic and how it has come to be distinct from other similar phenomena. ${ }^{17}$ The research is conducted by way of a normative legal research method, which typically includes the study of law principles, systematic study of law, research on the level of synchronization of law, research of legal history as well as comparative law research. ${ }^{18}$

The normative legal research carried out for this paper utilizes both primary and secondary legal sources, where the primary legal sources include Indonesian domestic laws and regulations as well as relevant case laws from the respective jurisdictions and the secondary legal sources refer to relevant law books, law journals, legal dictionaries and case commentaries. The source of case laws will include relevant jurisdictions such as Indonesia, The Netherlands, United Kingdom and where applicable, other common law countries.

Further, the comparative approach employed for this paper is based on English and Indonesian law. Comparative approach is defined as a research to

\footnotetext{
${ }^{17}$ Michael Salter and Julie Mason, Writing Law Dissertations: An Introduction and Guide to the Conduct of Legal Research, Pearson Education Limited, Dorset, 2007, p. 6.

${ }^{18}$ Theresia Anita Christiani, Normative and Empirical Research Methods: Their Usefulness and Relevance in the Study of Law as an Object, Procedia - Social and Behavioral Sciences 219, 2016, p. 202.
} 
compare the laws of a certain country with the laws of another country. ${ }^{19}$ The comparative approach herein will focus on the analytical method ${ }^{20}$ which enables explanation on the differences and commonalities between these two legal systems to a similar concept of 'contractual intention. While Indonesian law is chosen as a representative of civil law system, English law represents that of common law. Last but not least, research result will be analyzed using a qualitative method to provide answers to the aforesaid research questions.

\section{Result and Discussion}

Indonesian legal system adopts the Roman Germanic civil law system. One of the most fundamental characteristics of civil law system is that in applying and interpreting the law, the judges in the court will refer mainly to a code, or a statute in relation to the facts of the case. ${ }^{21}$ Contracts in Indonesia are mainly governed by Book III of the Indonesian Civil Code due to the application of the concordantie principle that was applied to pass down Dutch prevailing laws and regulations at the time of Indonesian independence. To some extent, Indonesian contract law is also governed by the local Adat law especially when it involves transaction amongst people of a certain indigenous population in a local setting. ${ }^{22}$

English law certainly adopts the Anglo-American common law system, ${ }^{23}$ by which it has spread to many other legal systems around the world particularly due to the application of the same rules towards the British colonies in the past. In the common law system, the principal source of law originates from the case-law of the common law courts and the courts of equity, and as such it functions very differently from Indonesian law which has a single coherent set of legal principles to be referred to to answer certain legal questions. However in terms of contract, English contract law follows similar reasonings of placing contract law within the

\footnotetext{
${ }^{19}$ Peter Mahmud Marzuki, Penelitian Hukum, Revised Edition, Penerbit Kencana, Jakarta, 2016, p. 173.

${ }^{20}$ Mark van Hoecke, Methodology of Legal Research, Law and Method No. 12, 2015, p. 13-14.

${ }^{21}$ Caslav Pejovic, "Civil Law and Common Law: Two Different Paths Leading to the Same Goal", Victoria University of Wellington Law Review, Volume 32, 2001, p. 819.

${ }^{22}$ Suharnoko, "Contract Law in a Comparative Perspective", Indonesia Law Review, Year 2 Volume 2, May August 2012, p. 117.

${ }^{23}$ Ernu Widodo, "Relevansi Sistem Civil Law dan Common Law dalam Peraturan Hukum Perjanjian Baku di Indonesia”, De Jure Jurnal Syariah dan Hukum Volume 2 Number 2, December 2010, p.122.
} 
law of obligations although without clear distinction between the law of contract and law of tort, as an example. ${ }^{24}$

Taking into account the differences as such, the research result will be presented in four subchapters, discussing the topics of 'Choice of Tests', 'Contractual Intention under English Law', 'Contractual Intention under Indonesian Law', and 'Impact of Contractual Intention towards Validity of Contract'.

\section{Choice of Tests}

Legal scholars commonly use the 'subjective' and 'objective' test to assess the merits of various matters, including those of contractual disputes. ${ }^{25}$ The objective test examines the parties' intentions by their declared external manifestation, ${ }^{26}$ basing it on the judgment of a reasonable person of whether or not the agreement is intended to be legally binding and as such the determination is made based on sole analysis on the external evidence. ${ }^{27}$ In the case of Smith $v$ Hughes, Blackburn J set out the following test to ascertain the intentions of the parties:

"if one parties intends to make a contract on one set of terms, and the other intends to make a contract on another set of terms, or, as it is sometimes expressed, if the parties are not ad idem, there is no contract, unless the circumsstances are such as to preclude one of the parties from denying that he has agreed to the terms of the other ... If, whatever a man's real intention may be, he so conducts himself that a reasonable man would believe that he was assenting to the terms proposed by the other party, and that other party upon that belief enters into the contract with him, the man thus conducting himself would be equally bound as if he had intended to agree to the other party's terms." 28

On this account, the point of view of such 'reasonable man' remains to be an important standard in viewing the parties intention by way of an objective test. The 'reasonable person' standard was further elaborated by Lord Denning in Merritt $v$. Merritt ${ }^{29}$ which states that "the court does not try to discover the intention by looking into the minds of the parties. It looks at the situation in which they were

\footnotetext{
${ }^{24}$ Cartwright, Op. Cit., p. 52.

${ }^{25}$ Subjective and objective tests are also used to assess intention in torts, criminal law and for sentencing purposes, see R. George Wright, "Objective and Subjective Tests in the Law," University of New Hampshire Law Review Volume 16 Number 1, 2017, p. 121 - 146.

${ }^{26}$ Cartwright, Op. Cit., p. 96.

${ }^{27}$ Wayne Barnes, "The French Subjective Theory of Contract: Separating Rhetoric from Reality," Tulane Law Review Volume 83, 2008, p. 359.

${ }^{28}$ Smith v Hughes (1871) LR 6 QB 597, 607.

${ }^{29}$ Merritt v Merritt (1970) EWCA Civ 6, 1 WLR 1211.
} 
placed and asks itself: Would reasonable people regard this agreement as intended to be legally binding?". The subjective test on the other hand refers to the personal, genuine intent of the parties, and the state of mind of the parties of the agreement by disregarding any external manifestation thereof. France is known to be partial towards the subjective theory, adopting a very uncommon position compared to the rest of the world. ${ }^{30}$ One logical reasoning behind preferring a subjective test is explained by James LJ in Tamplin v James, stating that "It is true that it is very difficult to prove what the state of a man's mind at a particular time is, but if it can be ascertained it is as much a fact as anything else." 31

By relying on the subjective test in determining the formation of a contract, the assessment would focus on whether the parties genuinely intend to enter into the agreement. As such, a party would only be bound by the contract in which they genuinely intended to enter into, whereby they will easily be able to escape from their contractual responsibility by invoking a state of misunderstanding. In the framework of contractual and commercial disputes, the courts in common law jurisdictions tend to focus on assessing the matters rather objectively, as it is considered to be more independent, public, and reasonable. 32

The seemingly different tests can never be pure in nature (in the sense that it completely excludes the other in the process), and yet there exists no single definition of subjective and objective theory, since countries select different viewpoints in the different stages of the contract. ${ }^{33}$ All in all, the results of the two are often similar however it puts emphasis on whether the inner psychological elements or the exteriorized indications need to be evaluated first.

\section{Contractual Intention under English Law}

English law requires two fundamental elements in determining whether a contract is valid and legally enforceable, namely consideration or the use of a deed, in addition to requiring consideration to avoid the occurrence of a gratuitous

\footnotetext{
${ }^{30}$ Barnes, Op. Cit., p. 360.

${ }^{31}$ Tamplin v James (1880) 15 ChD 215, 221 as cited in Cartwright, Op. Cit., p. 97.

${ }^{32} \mathrm{R}$. George Wright, "Objective and Subjective Tests in the Law," University of New Hampshire Law Review Volume 16 Number 1, 2017, p. 125.

33Joseph M. Perillo, "The Origins of the Objective Theory of Contract Formation and Interpretation," Fordham Law Review Volume 69 Issue 2, 2000, p. 429 - 431.
} 
promise. A party who only intends without creating a deed or giving consideration as a manifestation of his promise, is not legally bound by the agreement, ${ }^{34}$ although this is not applicable in specific regimes such as regarding domestic commitments since it is not regulated under the auspices of contract law. ${ }^{35}$

As Lush J expressed in Currie v Misa, "[ . . ] ] consideration may consist of either in some right, interest, profit or benefit accruing to the one party, or some forbearance, detriment, loss or responsibility given, suffered or undertaken by the other" ${ }^{\prime 6}$. Similar definition was also stated by Lord Dunedin in Dunlop Pneumatic Tyre Co Ltd v Selfridge \& Co Ltd as "[a]n act or forbearance of one party, or the promise thereof, is the price for which the promise of the other is bought, and the promise thus given for value is enforceable." 37

Further, three conditions must be fulfilled in order for a consideration to be considered acceptable under English Law. The first rule enunciates that the consideration must be sufficient, although it does not need to be adequate, as stated in the case judgments of inter alia Thomas $v$ Thomas $^{38}$ and Chappell \& Co. Ltd. $v$ Nestle Co. $L t d .{ }^{39}$. The meaning of the phrase 'sufficient' refers to the notion that value of consideration is allowed to not be economically adequate. Consideration can only be given after the agreement has been concluded, as adopted in the case of Roscorla v. Thomas. ${ }^{40}$ Lastly, the consideration must move from the promisee, and this can be enforced by third parties outside of the contract although it does not necessarily be given to the promisor. ${ }^{41}$

Where consideration is absent, promises can only be made binding if contained in a deed since otherwise it would be considered as an unsatisfactory gratuitous promise. Altruistic motives do not fall within the ambit of consideration under common law, and as such, altruistic promises like promises to give a gift

\footnotetext{
${ }^{34}$ Cartwright, Op. Cit., p. 155-156.

${ }^{35}$ Prince Saprai, "Balfour v Balfour and the separation of contract and promise," Legal Studies Volume 37 Issue 3, September 2017, p. 474.

${ }^{36}$ Currie v Misa (1875) LR 10 Ex 153; (1875-76) LR 1 App Cas 554 as explained in Syed Robayet Ferdous, Consideration of Contract in English Law \& Law of Bangladesh: A Comparative Study, Asian Affairs Volume 31 No. 1, 2009, p. 21-22.

${ }^{37}$ Dunlop Pneumatic Tyre Co Ltd v Selfridge \& Co Ltd [1915] AC 847 at 855.

${ }^{38}$ Thomas $v$ Thomas (1842) 2 QB 851; 114 ER 330

${ }^{39}$ Chappell \& Co. Ltd. v Nestle Co. Ltd. (1960) AC 87.

${ }^{40}$ Roscorla v Thomas (1842) 3 QB 234; 114 ER 496.

${ }^{41}$ Syed Robayet Ferdous, "Consideration of Contract in English Law \& Law of Bangladesh: A Comparative Study," Asian Affairs Volume 31 Number 1, 2009, p. 20.
} 
must be further legalized through a deed..$^{42}$ Further, a deed needs to be 'sealed'43 or signed by the party with the attestation of a witness in order for it to be enforceable. Inspite of this, English courts also occasionally hold promises enforceable if the parties' intention to be bound is evident even if the element of consideration is still questionable in nature. Some opinions even adopt further stance by stating that an agreement does not constitute as a binding contract if it is made without any intention to create legal relation. ${ }^{44}$ However, the currently prevailing central points of contract under English law favour reliance and certainty, and as such, intention is often objectively judged from the existence of consideration as a real form of exchange between the parties. ${ }^{45}$

A question then arises: how does English law assess the parties' contractual intention? As a rule, English courts view that the intentions of the parties should generally be interpreted objectively and this includes both in interpreting an already concluded written contract, as well as construing the communications of parties upon negotiation of contract related to the offer and acceptance therein. ${ }^{46}$ However, such contractual intention is only regarded as complementary in nature, ${ }^{47}$ and as such, does not automatically render the agreement to be void.

\section{Contractual Intention Under Indonesian Law}

The Indonesian Civil Code states the following conditions that must be fulfilled in order to make a valid agreement: consent of the individuals who are bound thereby; capacity to enter into a legal relation; specific subject matter; and a permitted cause. ${ }^{48}$ Such consent cannot be accepted if it is based on a mistake or obtained by way of duress or fraud..$^{49}$ Intention hence can be concluded to be part

${ }^{42}$ Dena Valente, Enforcing Promises: Consideration and Intention in the Law of Contract, Dissertation, Bachelor of Laws (Honours) of University of Otago, Otago, 2010, p. 16. See also: Jack Beatson, Andrew Burrows and John Cartwright, Anson's Law of Contract, 29th Edition, Oxford University Press, Oxford, 2010, p. 76-78.

${ }^{43}$ Historically, a deed must be sealed with the formal wax seal without having to be signed. The seal was used to indicate the party's consent in making the deed. However, Section 1 of the Law of Property (Miscellaneous Provisions) Act 1989 and Companies Act 2006 have provided modern option of using signature instead of having to have the deed sealed.

${ }^{44}$ Sir Guenter Treitel, The Law of Contract, Tenth Edition, Sweet \& Maxwell, London, 1999, p. 149.

${ }^{45}$ Eva Steiner, French Law: A Comparative Approach, Oxford University Press, Oxford, 2018, p. 227.

${ }^{46}$ Jack Beatson, Andrew Burrows and John Cartwright, Anson's Law of Contract, 29 ${ }^{\text {th }}$ Edition, Oxford University Press, Oxford, 2010, p. 253.

${ }^{47}$ Cartwright, Op. Cit., p. 156.

${ }^{48}$ Article 1320 of the Indonesian Civil Code.

${ }^{49}$ Article 1321 of the Indonesian Civil Code. 
of the first requirement as it is based on the notion of "meeting of minds", which means that the parties must have the same level of understanding with regard to the terms regulated under the contract before having the grounds to intend to be bound by the contract.

Intention does not always have to be explicitly stated in the contract, but can also be inferred from the parties' actions or other corroborating factors that divulge such intention. The term 'consent' is not defined specifically in the Indonesian Civil Code, but Herlien Budiono defines consent as not only a 'consent' to be bound, but also a 'consent' to receive performance (prestasi) ${ }^{50}$. Consent, which serves as the manifestation of the intention of the parties, involves two important elements namely offer and acceptance. The concept of offer and acceptance under English and Indonesian laws are inherently similar. ${ }^{51}$ It recognizes the offer (aanbod) as the esensialia element of the agreement ${ }^{52}$ whereby the intention of the offeror is automatically indicated therein. 53

Further, legal scholars in Indonesia as well as in the Netherlands have formulated three theories which can be used to analyze contractual bound based on contractual intention or statement. ${ }^{54}$ These theories are known as will theory (wilsleer; wilstheorie), statement theory (verklaringsleer; verklaringstheorie), and trust theory (vertrouwensleer; vertrouwenstheorie). .55

In wilstheorie, contractual relation will only be established based on and only to the extent of the statement which corresponds with the intention. Consequently, any statement that does not coincide with the party's wish will not be considered binding. ${ }^{56}$ The verklaringstheorie holds that a party is bound by their statement,

\footnotetext{
${ }^{50}$ Herlien Budiono, Ajaran Umum Hukum Perjanjian dan Penerapannya di Bidang Kenotariatan, PT. Citra Aditya Bakti, Bandung, 2009, p. 73.

${ }^{51}$ Ricardo Simanjuntak, Hukum Kontrak: Teknik Perancangan Kontrak Bisnis, KontanPublishing, Jakarta, 2011, p. 151. See also Agus Yudha Hernoko, Hukum Perjanjian: Asas Proporsionalitas dalam Kontrak Komersial, Penerbit Kencana, Jakarta, 2013, p. 162-172.

${ }^{52}$ Agus Yudha Hernoko, Op. Cit., p. 162.

${ }^{53}$ Ricardo Simanjuntak, Op. Cit., p.153.

${ }^{54}$ There are also other theories regarding formation of contract that do not concern intention, namely the statement theory (uitingstheorie), sending theory (verzendingstheorie), the knowledge theory (vernemingstheorie), and the acceptance theory (ontvangstheorie).

${ }^{55}$ Agus Yudha Hernoko, Op. Cit., p. 165-166.

${ }^{56}$ Irawan Soerodjo, The Development of Indonesian Civil Law, Scientific Research Journal, Volume IV Issue IX, September 2016, p. 32.
} 
regardless of whether or not such statement corresponds with their genuine intention. ${ }^{57}$

The vertrouwenstheorie holds that the party's statement which is objectively trustworthy, that such statement is resulted from the party's own intention. The vertrouwenstheorie is considered to be derived from the verklaringstheorie, although taking a softer and more gentle rationale. ${ }^{58}$ Having these three theories in place, more thorough analysis needs to be conducted in order to find out the position that Indonesian law currently adopts since there are contradictory provisions in the Indonesian Civil Code with regard to the utilization of the aforesaid theories in the interpretation of contract. 59

The position of objectivity adopted in the Indonesian legal system with regard to holding the party's intention have been confirmed by various legal scholars. Elly Erawati and Herlien Budiono stated that "a legal action requires an intention to be directed towards creating certain legal consequences as manifested in a statement." This notion is elaborated further in the following explanation:

"Even if the parties did not read or know the content of a deed, either partially or as a whole, they have consciously intended to be "bound" by the content of the deed which applies to themselves. [ ... ] Almost all standard agreements are signed without the parties knowing or reading the (exact) content written within. However, the fact that the agreement has been signed creates ground for trust or belief that the signee really knows and intends what has been stated by virtue of signing the agreement." 60

The Dutch law's position in this regard may also be relevant for discussion since the current legal regime is based on the Dutch colonial laws and regulations. In the 1981 judgment of Ermes v. Haviltex, the Netherlands Hoge Raad gave the following conclusion:

"The question of how the relationship between parties is regulated in a written agreement and whether this contract leaves a gap that needs to be completed, cannot be answered on the basis of just a purely linguistic interpretation of the

${ }^{57}$ Agus Yudha Hernoko, Op. Cit., p. 166.

${ }^{58}$ Elly Erawati and Herlien Budiono, Penjelasan Hukum tentang Kebatalan Perjanjian, PT. Gramedia, Jakarta, 2010, p. 68.

${ }^{59}$ For example, Article 1343 of the Civil Code tends to lean towards the subjective interpretation by analyzing the intent of the parties involved, whereas Article 1342 is more inclined towards an objective interpretation based on the clarity of the wording.

${ }^{60}$ Ibid., p. 70. 
provisions of that particular contract. In order to answer that question, the determining factor has to be the meaning that the parties, under the specific circumstances, reasonably could have attributed to the provisions in that contract as well as the reasonable expectations that they could derive from one another as a result. In determining such context additional factors may be of influence, such as to what social classes the parties come from and what legal knowledge can be expected of them." 61

This is known as the Haviltex standard, and thus it can be concluded that the Dutch legal system adopts what is known as the "subjective-objective" standard. Nieuwenhuis also confirms this proposition by stating that the Dutch legal system adopts "de dubbele grondslag" theory ${ }^{62}$, and this is incorporated into Article 3:33 and 3:35 of the New Netherlands Civil Code (Nieuw Burgerlijk Wetboek). In contrast, the drafters of the Old Netherlands Civil Code viewed that contractual intention should be disregarded in the case where clear and comprehensive words are already exhibited in the contract. ${ }^{63}$ This remains to prevail in Article 1342 of the Indonesian Civil Code, which prohibits deviation by way of interpretation once the statement is clear. In other words, further interpretation concerning the parties intention may only be conducted if the statement is not clear.

\section{Impact of Contractual Intention Towards Validity of Contract}

The Indonesian Civil Code has clearly stated that the consent given by parties will not be valid if it is based on a mistake (kekhilafan or dwaling). ${ }^{64}$ Mismatch of intention, or in another word a mistake, takes on different forms that can be categorized further into situations which involve misunderstanding of statement, and conditions where the statement is clear (without possibility for misunderstanding) but uttered without genuine intention.

In general, statements that are unclear or misunderstood will not result in the formation of a contract, since there are no consensus formed between the parties. However, if the misunderstanding is resulted from the parties' incautious or

${ }^{61}$ Ermes c.s. v. Haviltex (HR 13 March 1981, NJ 1981, 635) as explained in Oguz Kirman, (re)Defining the Entire Agreement Clause, Thesis, Research Master in Law \& Dutch Private Law of Tilburg University, Tilburg, 2016, p. 50.

${ }^{62}$ As explained in Agus Yudha Hernoko, Op. Cit., p.166.

${ }^{63}$ C. Asser-A.S. Hartkamp, Verbintenissenrecht, Algemene Leer der Overeenkomsten, Tiende Druk, W.E.J. Tjeenk Willink, Deventer, 1997, p. 286 as cited in Muhammad Syaifuddin, Op. Cit., p. 327. See also Article 1342 of the Indonesian Civil Code.

${ }^{64}$ Article 1321 of the Indonesian Civil Code. 
reckless action when expressing the statement, provisions on the annullability of contract based on mistake will prevail, ${ }^{65}$ whereby this misunderstanding may also be resolved by methods of interpreting an agreement as regulated under the Indonesian Civil Code. 66

The second category is more complicated, because the difficulty lies on finding out the uncommunicated true intention of the parties. For instance, a statement may be expressed by a party, although the internal state of mind of the aforesaid party does not want to accept the consequences resulted from such statement. In this case, based on the trust theory, an agreement has been formed as the other party has reasonably relied on the statement. Another example of uncommunicated intention would be witty remarks. Jokes can fall under the ambit of reservatio mentalis, but further analysis needs to be carried out towards whether the other party has carried out an "acceptance" in a serious and reasonable manner.

Additionally, parties may conclude what is known as a mock up agreement, or a simulation agreement, in which neither of them actually intend to create legal relations from the process. In this situation, the first requirement of validity of agreement is consciously avoided by the parties and consequently the agreement does not bind any of the parties in question.

Similarly, it has been argued that a Memorandum of Understanding does not bind the parties because of the lack of intention to create legal relation. This conception on how the lack of intention to create legal relation should invalidate the binding force of a Memorandum of Understanding was once brought up in the case of PT. Jaya Makmur Bersama v PT. Pengembang Pariwisata Bali. The matter was decided by the District Court of Denpasar, and was later brought to cassation and judicial review. However, the Memorandum of Understanding was held to constitute as a valid agreement under Article 1338 of the Indonesian Civil Code, and consequently is still binding towards the parties. Ergo, the fact that the intention had yet to exist was considered to be insignificant in assessing the validity of the agreement itself. ${ }^{67}$

\footnotetext{
${ }^{65}$ Elly Erawati and Herlien Budiono, Op. Cit., p. 71.

${ }^{66}$ See Articles 1342 - 1351 of the Indonesian Civil Code.

${ }^{67}$ Supreme Court of Indonesia Decision Number 1788 K/Pdt/2014 and Number 472 PK/Pdt/2017.
} 
Nevertheless, the mistake will only render an agreement invalid if the mistake is regarding the subject matter of the agreement. ${ }^{68}$ As a conclusion, since the mistake concerns the first requirement of an agreement under Art. 1320 of the Indonesian Civil Code, the agreement will then be nullable.69 Effectuality will remain if neither of the parties submit a request for annulment. If the contract is annulled based on this ground, a restitution will be conducted to return the parties' conditions to their original state prior to the conclusion of the contract. ${ }^{70}$

Comparable to the Indonesian legal regime, validity of a contract may be impaired under English law by virtue of a mistake. ${ }^{71}$ English law further distincts two categories of vitiated contracts, namely a 'void' contract and a 'voidable' contract. A 'void' contract is a contract that is void ab initio, and discernibly, a contract with an element of a mistake does not fall under this category.

In consequence, a contract with an element of mistake is considered as a 'voidable' contract, by which it was validly formed through a proper offer, acceptance and consideration, however the defect exists in the moment of its formation. ${ }^{72}$ Historically, English courts used to render a contract to be 'voidable' based on the instigation of the disadvantaged party. This has changed over time to become an 'all or nothing' approach, where a common mistake shared by both parties in the agreement will automatically render the agreement to be 'void' ${ }^{73}$

Still similar to Indonesian law, a disadvantaged innocent party may submit a request to make the agreement void. However, it is worth to notice that under English law, parties can seek to 'rescind' a contract in the case of a misrepresentation by which they can just carry out the process by giving notice to the representor with regard to their choice of rescinding the contract. ${ }^{74}$ Once a contract is rescinded, it will return to its original state (considered as ab initio) and parties must make restitution accordingly. Further, English courts do recognize the existence of the 'intention to create legal relations' doctrine, however keeping their

\footnotetext{
${ }^{68}$ Article 1322 of the Indonesian Civil Code.

${ }^{69}$ Subekti, Pokok-Pokok Hukum Perdata, PT. Intermasa, Jakarta, 2005, p. 135.

${ }^{70}$ Ahmadi Miru, Hukum Kontrak dan Perancangan Kontrak, Raja Grafindo Persada, Yogyakarta, 2007, p. 78.

${ }^{71}$ Cartwright, Op. Cit., p. 159.

${ }^{72}$ Ibid., p. 161.

${ }^{73}$ David Capper, “Common Mistake in Contract Law," Singapore Journal of Legal Studies, December 2009, p.

${ }^{74}$ Cartwright, Op. Cit., p. 179.
} 458. 
stance that the role of intention is merely subsidiary. ${ }^{75}$ This means that as long as the parties intentions have passed the objective test, their true intentions will be irrelevant and the contract will be kept.

Consequently, adjudication of domestic courts are especially risky when the process involves two different legal systems from different legal jurisdictions. Parties can of course pursue other means of dispute resolution, such as through international arbitration or through mediation, but a uniform law for international sales is still of great importance.

\section{Application of a Uniform Law for International Sales}

Cross-border businesses require legal certainty and predictability in order to thrive, especially when it comes to undergoing dispute resolution processes. One of the key element of having a dispute resolution outcome that is acceptable for both parties lies in the applicable law. As a result, it is now a common practice to use a uniform regime in a cross border contract, such as the United Nations Convention on Contracts for the International Sales of Goods (hereinafter referred as 'CISG'), binding 89 parties to the Convention. ${ }^{76}$ European Union has tried to conduct similar approach through launching the proposal for a Common European Sales Law (hereinafter referred as 'CESL') in 11 October 2011,77 though it is still in the process of being drafted and has yet to be finalized.

With regard to contractual intention, CISG provides that "A proposal for concluding a contract addressed to one or more specific persons constitutes an offer if it is sufficiently definite and indicates the intention of the offeror to be bound in case of acceptance," 78 whereby the indication of intention must reach the addressee "when it is made orally to him or delivered by any other means to him personally, to his place of business or mailing address or, if he does not have a place of business or mailing address, to his habitual residence." 79

\footnotetext{
${ }^{75}$ Ibid., p. 156.

${ }^{76}$ Data per 7 November 2018, accessed in http://www.uncitral.org/uncitral/en/uncitral_texts/ sale_goods/1980CISG_status.html on 7 November 2018.

${ }^{77}$ Ruben de Graaff, Yvo Rampersad, Pieter de Tavernier and Jeroen van der Weide, "From Here to Eternity: The Proposal for a Regulation on a Common European Sales Law (CESL", European Review of Private Law, Issue 4 Volume 21, 2013, p. 1145.

${ }^{78}$ Article 14 (1) of the United Nations Convention on Contracts for the International Sales of Goods.

${ }^{79}$ Article 24 of the United Nations Convention on Contracts for the International Sales of Goods.
} 
As such, it can be seen that even contractual intention is regarded to be very important under the CISG, making the contract to be non existent due to the absence of offer if the intention to be bound has not reached the addressee. The intention of the offeror becomes a subjective criterion under the CISG, as such the offeror must show readiness to be bound in the anticipation of an acceptance. The intention therein forms as one of the requirements for creation of an offer, aside for sufficient definiteness of a proposal. 80

The issue of "intention to be bound" under the CISG was also the central point of the Hanwha Corporation V. Cedar Petrochemicals, Inc. ${ }^{81}$ case, where the parties come from two different jurisdictions with two different legal systems: Hanwha Corporation is a Korean company which is ruled by a Civil Law system, meanwhile Cedar Petrochemicals is from the United States which adopts Common Law system. In this case, it was construed by the Court of New York that "subjective intent of the parties, when properly applicable, takes priority over other tools of interpretation" 82 meaning that intention of the parties still stay on top of the hierarchy.

The court found that there had not been an effective offer under the CISG because the intention to be bound was not being revealed when the bidding process was conducted. The court found that no final agreement was reached, and that no intention could be observed from the parties' exchange in terms of the business behaviour.

\section{Conclusion}

English and Indonesian law employ different methods to assess contractual intention of the parties, especially with regard to interpreting unclear contracts in the event of a dispute. English courts assess the intention of the parties through the eyes of objectivity, while viewing intention as supplementary in nature as long as the three main requirements of contract are fulfilled: offer, acceptance and to some

\footnotetext{
$130-131$

${ }^{80}$ Belkis Vural, "Formation of Contract According to the CISG", Ankara Bar Review, Volume 1, 2013, p.

${ }^{81}$ Hanwha Corporation V. Cedar Petrochemicals, Inc. 2011 WL 165404 (S.D.N.Y.)

${ }^{82}$ Clayton P. Gillette, Subjective Intent in American Contract Law and the CISG, accessed in https://blogs.law.nyu.edu/transnational/2011/02/subjective-intent-in-american-contract-law-and-the-cisg/ on 5 November 2018.
} 
extent, consideration. Indonesian law appears to examine contracts by way of a subjective-objective standard, though intention of the parties form part of the first requirement of contract under Article 1320 of the Indonesian Civil Code, namely consent. As long as consent is proven to exist, genuine intention of the parties may be put aside in deciding a contractual dispute.

Mismatched contractual intentions, or the absence of meeting of minds, render the contracts to be 'voidable' under both legal systems. Indonesian law recognizes the doctrine of mistake and providing methods to interpret a contract in the case of misunderstanding under the Indonesian Civil Code. English law seems to put a harsher stance on revoking a contract, especially when there is a common mistake between the contracting parties which will render the contract to be void. In this situation, parties are obliged to carry out restitution to return to the precontractual conditions. The position of contractual intention becomes significantly higher when referring to the CISG rules as a viable international convention option for the parties.

Taking into account the differences in the two legal systems, drafters should be more thorough and cautious in drafting the exact provision in the contract in order to avoid unintended mistake that may provide room for the other party to avoid carrying out their contractual obligation.

\section{Bibliography}

\section{Books}

Beatson, Jack, Burrows, Andrew and Cartwright, John, Anson's Law of Contract, 29th Edition, Oxford University Press, Oxford, 2010.

Budiono, Herlien, Ajaran Umum Hukum Perjanjian dan Penerapannya di Bidang Kenotariatan, PT. Citra Aditya Bakti, Bandung, 2009.

Cartwright, John, Contract Law: An Introduction to the English Law of Contract for the Civil Lawyer, Third Edition, Oxford, 2016.

Erawati, Elly Erawati and Budiono, Herlien, Penjelasan Hukum tentang Kebatalan Perjanjian, PT. Gramedia, Jakarta, 2010.

Hernoko, Agus Yudha, Hukum Perjanjian: Asas Proporsionalitas dalam Kontrak Komersial, Penerbit Kencana, Jakarta, 2013.

Martin, Elizabeth A., Oxford Dictionary of Law, Fifth Edition, Oxford, 2003. 
Marzuki, Peter Mahmud, Penelitian Hukum, Revised Edition, Penerbit Kencana, Jakarta, 2016.

Miru, Ahmadi, Hukum Kontrak dan Perancangan Kontrak, Raja Grafindo Persada, Yogyakarta, 2007.

Salter, Michael and Mason, Julie, Writing Law Dissertations: An Introduction and Guide to the Conduct of Legal Research, Pearson Education Limited, Dorset, 2007.

Simamora, Y. Sogar, Hukum Kontrak: Prinsip-Prinsip Hukum Kontrak Pengadaan Barang dan Jasa Pemerintah di Indonesia, LaksBang Pressindo, Surabaya, 2017.

Simanjuntak, Ricardo, Hukum Kontrak: Teknik Perancangan Kontrak Bisnis, KontanPublishing, Jakarta, 2011.

Steiner, Eva, French Law: A Comparative Approach, Oxford University Press, Oxford, 2018.

Subekti, Pokok-Pokok Hukum Perdata, PT. Intermasa, Jakarta, 2005.

Syaifuddin, Muhammad, Hukum Kontrak: Memahami Kontrak dalam Perspektif Filsafat, Teori, Dogmatik, dan Praktik Hukum (Seri Pengayaan Hukum Perikatan), CV. Mandar Maju, Bandung, 2012.

Treitel, Sir Guenter, The Law of Contract, Tenth Edition, Sweet \& Maxwell, London, 1999.

\section{Internet}

Clayton P. Gillette "Subjective Intent in American Contract Law and the CISG", accessed in https://blogs.law.nyu.edu/transnational/2011/02/ subjective-intent-in-american-contract-law-and-the-cisg/ on 5 November 2018.

\section{Journals}

Barnes, Wayne, "The French Subjective Theory of Contract: Separating Rhetoric from Reality," Tulane Law Review Vol. 83, 2008

Calleros, Charles, "Cause, Consideration, Promissory Estoppel, and Promises Under Deed: What our Students Should Know about Enforcement of Promises in A Historical and International Context," Chicago-Kent Journal of International and Comparative Law Volume 13, (2012)

Capper, David, "Common Mistake in Contract Law," Singapore Journal of Legal Studies, December 2009.

Chandrika, M.P., "A Comparative Analysis of U.K. and Indian Provision relating to Intention under Law of Contract," International Journal of Law and Legal Jurisprudence Studies Vol. 3 Issue 4, 2016.

Christiani, Theresia Anita, "Normative and Empirical Research Methods: Their Usefulness and Relevance in the Study of Law as an Object," Procedia Social and Behavioral Sciences 219, 2016. 
de Graaff, Ruben, Rampersad, Yvo, et. al., "From Here to Eternity: The Proposal for a Regulation on a Common European Sales Law (CESL", European Review of Private Law, Issue 4 Volume 21, 2013.

Fandl, Kevin J., "Cross-Border Commercial Contracts and Consideration," Berkeley Journal of International Law Vol. 34 Issue 2, Fall 2016.

Ferdous, Syed Robayet, "Consideration of Contract in English Law \& Law of Bangladesh: A Comparative Study," Asian Affairs Vol. 31 No. 1, 2009.

Gulati, Bhawna, "'Intention to Create Legal Relations': A Contractual Necessity or an Illusory Concept", Beijing Law Review Vol. 2 No. 3, 2011.

Pejovic, Caslav, "Civil Law and Common Law: Two Different Paths Leading to the Same Goal", Victoria University of Wellington Law Review, Volume 32, 2001.

Perillo, Joseph M., "The Origins of the Objective Theory of Contract Formation and Interpretation," Fordham Law Review Volume 69 Issue 2, 2000.

Putra, Fani Martiawan Kumara, "Paksaan Ekonomi dan Penyalahgunaan Keadaan Sebagai Bentuk Cacat Kehendak dalam Perkembangan Hukum Kontrak", Yuridika Vol. 30 No. 2, May 2015.

Saprai, Prince, "Balfour v Balfour and the separation of contract and promise," Legal Studies Volume 37 Issue 3, September 2017.

Soerodjo, Irawan, “The Development of Indonesian Civil Law," Scientific Research Journal, Volume IV Issue IX, September 2016.

Suharnoko, "Contract Law in a Comparative Perspective", Indonesia Law Review, Year 2 Volume 2, May - August 2012.

Tikniute, Agne and Dambrauskite, Asta, "Understanding Contract Under the Law of Lithuania and Other European Countries", Jurisprudence Vol. 18 Issue 4, 2011.

Van Hoecke, Mark, "Methodology of Legal Research," Law and Method No. 12, 2015.

Vural, Belkis, "Formation of Contract According to the CISG", Ankara Bar Review, Volume 1, 2013.

Widodo, Ernu, "Relevansi Sistem Civil Law dan Common Law dalam Peraturan Hukum Perjanjian Baku di Indonesia", De Jure Jurnal Syariah dan Hukum Volume 2 Number 2, December 2010.

Wright, R. George, “Objective and Subjective Tests in the Law," University of New Hampshire Law Review Volume 16 Number 1, 2017.

\section{Case Decisions}

\section{United Kingdom}

Ermes c.s. v. Haviltex (HR 13 March 1981, NJ 1981, 635)

Thomas $v$ Thomas (1842) 2 QB 851; 114 ER 330

Chappell E Co. Ltd. v Nestle Co. Ltd. (1960) AC 87. 
Roscorla v Thomas (1842) 3 QB 234; 114 ER 496

Currie v Misa (1875) LR 10 Ex 153; (1875-76) LR 1 App Cas 554

Dunlop Pneumatic Tyre Co Ltd v Selfridge \& Co Ltd [1915] AC 847

Merritt v Merritt (1970) EWCA Civ 6, 1 WLR 1211.

Smith $v$ Hughes (1871) LR 6 QB 597, 607

\section{United States}

Hanwha Corporation V. Cedar Petrochemicals, Inc. 2011 WL 165404 (S.D.N.Y.)

\section{Indonesia}

Supreme Court of Indonesia Decision Number 1788 K/Pdt/2014 and Number 472 PK/Pdt/2017.

\section{Thesis and Dissertation}

Kirman, Oguz, (re)Defining the Entire Agreement Clause, Thesis, Research Master in Law \& Dutch Private Law of Tilburg University, Tilburg, 2016.

Valente, Dena, Enforcing Promises: Consideration and Intention in the Law of Contract, Dissertation, Bachelor of Laws (Honours) of University of Otago, Otago, 2010. 